\title{
Selective targeting of transforming growth factor-beta1 into TCR/CD28 signalling plasma membrane domains silences $T$ cell activation
}

\author{
Thomas Harder ${ }^{*}$, Karina Guttek, Lars Philipsen, Luca Simeoni, Burkhart Schraven and Dirk Reinhold
}

\begin{abstract}
TGF $\beta 1$ (Transforming Growth Factor-beta1) is a versatile regulator of T cell immune responses. Depending on its context in the immunological environment, TGF $\beta 1$ guides T cells toward specific activation programs including $T_{H} 17$ and regulatory $T$ cell activities. Moreover, TGF $\beta$ signals function in immune homeostasis by directly attenuating $T$ cell effector activities. We uncovered a novel context under which TGF $\beta 1$ stringently and reversibly silences activation responses of resting human T cells to TCR/CD28 stimulating surfaces:

Using ligand-presenting beads, TGF 31 and TCR/CD28-activating signals were directed into defined plasma membrane domains of T cells. Selective targeting of TGF $\beta 1$ cytokine into TCR/CD28 signalling plasma membrane domains held back early response of TCR-proximal tyrosine phosphorylation and bead engulfment at activation sites. Consequently, downstream induction of proliferation and cytokine secretion were stringently attenuated. After extended incubation with TGF $\beta 1$-presenting beads, silenced T cells became receptive again to activation by renewed TCR/CD28-stimuli, indicating that the unresponsive state of T cells was reverted and did not reflect long-lasting anergy or decrease in T cell viability. These findings outline a new strategy of physically linking TGF 1 and TCR-activating functions for the treatment of disease and pathological conditions which are caused by unwanted T cell activity.
\end{abstract}

Keywords: Silencing of T lymphocyte activation, TGF $\beta 1$, Plasma membrane compartmentalisation, Biologicals for treatment of transplant rejection, Allergies, Autoimmunity

\section{Lay abstract}

The human body is permanently exposed to pathogens like viruses which infect cells of the body and cause disease. In order to control pathogen attack, humans and animal species have evolved a sophisticated defence; the immune system. The immune system needs to recognise pathogens, fend them off, and memorise these pathogens in case they reappear. However, loss of control over these defence mechanisms is a cause of many serious diseases like diabetes, inflammatory bowel disease, multiple sclerosis, and allergies. In the present study we developed a set-up under which key cells of the immune system; socalled $\mathrm{T}$ cells, are held in a dormant state under which they do not activate their functions in immune defence. This new route of $\mathrm{T}$ cell-silencing promises a lead toward

\footnotetext{
* Correspondence: tharder@faciendum.org

Institute for Molecular and Clinical Immunology, Otto-von-Guericke University Magdeburg, Leipziger Straße 44, D 39120 Magdeburg, Germany
}

treatment of numerous important diseases which are caused by unwanted action of T cells like diabetes, inflammatory bowel disease, multiple sclerosis, and allergies.

\section{Background}

Transforming growth factor-beta (TGF $\beta$ ) has pleiotropic roles in steering differentiation and homeostasis of cells, tissues, and organs [1]. TGF $\beta 1$ is a versatile regulator of T cell immune responses and guides $\mathrm{CD} 4+\mathrm{T}$ lymphocytes toward specific activities of the $\mathrm{T}_{\mathrm{H}} 17$ and Treg phenotypes $[2,3]$. Additionally, TGF $\beta$ signals restrain T cell activities and thereby directly function in immune homeostasis $[4,5]$. Functions of TGF $\beta 1$ in safeguarding a healthy balance of the immune system were highlighted by severe multiorgan inflammatory disease of TGF $\beta 1$-deficient mice $[6,7]$. Dysfunction of TGF $\beta 1$-mediated T cell balance is associated with autoimmune disorders and thus molecular 
principles of TGF $\beta$-regulation of $\mathrm{T}$ cell activities are of important medical interest.

TGF $\beta$ signals are transduced by TGF $\beta$ receptors (TGF $\beta R$ ) I and II which catalyse serine/threonine phosphorylation of SMAD proteins. Phosphorylated SMADs cooperate with various transcription factors to activate cell-specific gene transcription programs. TGF $\beta$ receptors, cytoplasmic and nuclear factors, and chromatin structure determine context-dependent cellular outcomes of these canonical TGF $\beta$ signalling cascades. Additional non-canonical TGF $\beta$ signalling pathways exist, many of which are initiated at the platform of the plasma membrane for example by targeting PI3K/AKT pathway and Rho-GTPase signalling cascades [1].

Under physiological, resting conditions TGF $\beta$ is held in an inactive latent configuration in a complex with Latency Associated Peptide (LAP) which hinders TGF $\beta$ cytokine binding to TGF $\beta$ receptors. Latent TGF $\beta$ gets activated when active cytokine is released from TGF $\beta$ LAP complex. Various mechanisms mediate activation of TGF $\beta$ : These include specific binding of proteins like thrombospondin to LAP, LAP proteolytic cleavage, $\alpha v$ integrin-binding and cytoskeletal force along membranebound TGF $\beta$-LAP complex [8-10].

$\mathrm{T}$ cell antigen receptor (TCR), upon interaction with a cognate peptide-MHC ligand, transduces key signals which activate resting $\mathrm{T}$ lymphocytes to proliferate and perform immune effector functions. These signals are propagated to the $\mathrm{T}$ cell interior via tyrosine kinase activation and induction of signalling complexes which mediate intracellular signalling reactions and respective $\mathrm{T}$ cell responses [11]. A costimulatory second signal is mediated by surface protein CD28 on engagement with CD80/86 antigens on antigen-presenting cells and is required for full activation of resting $\mathrm{T}$ lymphocytes to proliferate and perform effector functions like secretion of cytokines [12].

TGF $31-L A P$ is presented on the surface of CD4+ $\mathrm{CD} 25+\mathrm{T}$ cells and was proposed to exert regulatory functions upon contact with effector T cells $[13,14]$. On FoxP3+ regulatory T cells (Tregs) TGF $\beta 1$-LAP is bound to trans-plasma membrane protein GARP (glycoprotein A repetitions predominant protein) $[15,16]$. siRNA-mediated depletion of GARP in human Tregs reduced, but did not abolish, suppressive activity of FoxP3+ Tregs in vitro, indicating contribution of TGF $\beta 1$ surface presentation as well as additional functions to regulatory activities of Tregs [16]. A distinct population of FoxP3+ human Tregs expresses MHC class II and was shown to specifically mediate early suppression of $\mathrm{T}$ cell activation directly upon cell/cell contact [17].

TCR activation and TGF $\beta 1$-signals may likewise act together at the immunological synapse between $\mathrm{CD} 4+\mathrm{T}$ cells and antigen-presenting dendritic cells (DC) in order to induce Treg and $\mathrm{T}_{\mathrm{H}} 17$ activities. These DCs need to express matching MHC class II to activate TCR and $\alpha v$ integrins which present TGF $\beta 1$ to T cells [18-20].

Hence, simultaneous presentation of TGF $\beta 1$ and TCRactivating ligands on cell surfaces is a recurring motif in modulation of $\mathrm{T}$ cell activities. Here we used defined ligand-coated beads as artificial surfaces to present activating stimuli to resting human $T$ cells in vitro: Simultaneous presentation of TGF $\beta 1$ and TCR/CD28-signals in common $\mathrm{T}$ cell plasma membrane signalling domains stringently and reversibly held back activation responses of $\mathrm{T}$ cells. These findings identified lateral plasma membrane compartmentalization of TGF $\beta 1$ signalling as cell biological context under which $\mathrm{T}$ cell activation responses are attenuated and suggest new strategies for treatment of disease and pathological conditions which are caused by unwanted $\mathrm{T}$ cell activity.

\section{Results and discussion}

\section{Presentation of TGF $\beta 1$ on TCR/CD28-activating beads} silences $T$ cell activation responses

Isolated resting human $\mathrm{T}$ lymphocytes were activated via TCR/CD28 by conjugation with protein G-coated microbeads which were coated with anti-CD3 and anti-CD28 mAbs (monoclonal antibodies) and, additionally, with mAb against the LAP subunit of latent TGF $\beta$-LAP complex. Defined amounts of TGF $\beta 1$-LAP were loaded onto antiCD3/CD28/LAP beads via anti-LAP antibodies. TGF 31 LAP-loading silenced proliferative response of $\mathrm{T}$ cells to bead-bound anti-CD3 and anti-CD28 mAbs in strictly dose-dependent manner; first evident around $2 \mathrm{ng} / \mathrm{ml}$ final concentration and nearing completion at $50 \mathrm{ng} / \mathrm{ml}$ (Figure 1A).

We estimated contribution of steric impediment of antibody access to T cells by bead-bound TGF $\beta 1$-LAP to attenuation of $\mathrm{T}$ cell proliferation response. In parallel experiments TCR/CD28-activating beads were loaded with inactive LAP and with latent TGF 1 -LAP. Inactive LAP, when loaded on T cell-activating anti-CD3/CD28/ LAP beads, partially inhibited proliferation at highest doses (Figure 1B) indicating that steric impediment of activating antibody access contributes to the inhibitory effect. This, however, can be discriminated from strictly dose-dependent and stringent antiproliferative activity of TGF $\beta 1$-LAP on activating beads.

We then assessed whether presentation of TGF $\beta 1$-LAP on anti-CD3/CD28/LAP beads also attenuated early response of tyrosine phosphorylation of TCR-proximal signalling proteins [21]. Western blots of whole cell lysates of TCR/CD28 activating bead-stimulated T cells were performed over a time course of $30 \mathrm{mins}, 37^{\circ} \mathrm{C}$ incubation. These blots reiterated TCR triggering-induced tyrosine phosphorylation of tyrosine kinase ZAP-70, transmembrane Linker for Activation of T cells (LAT) 

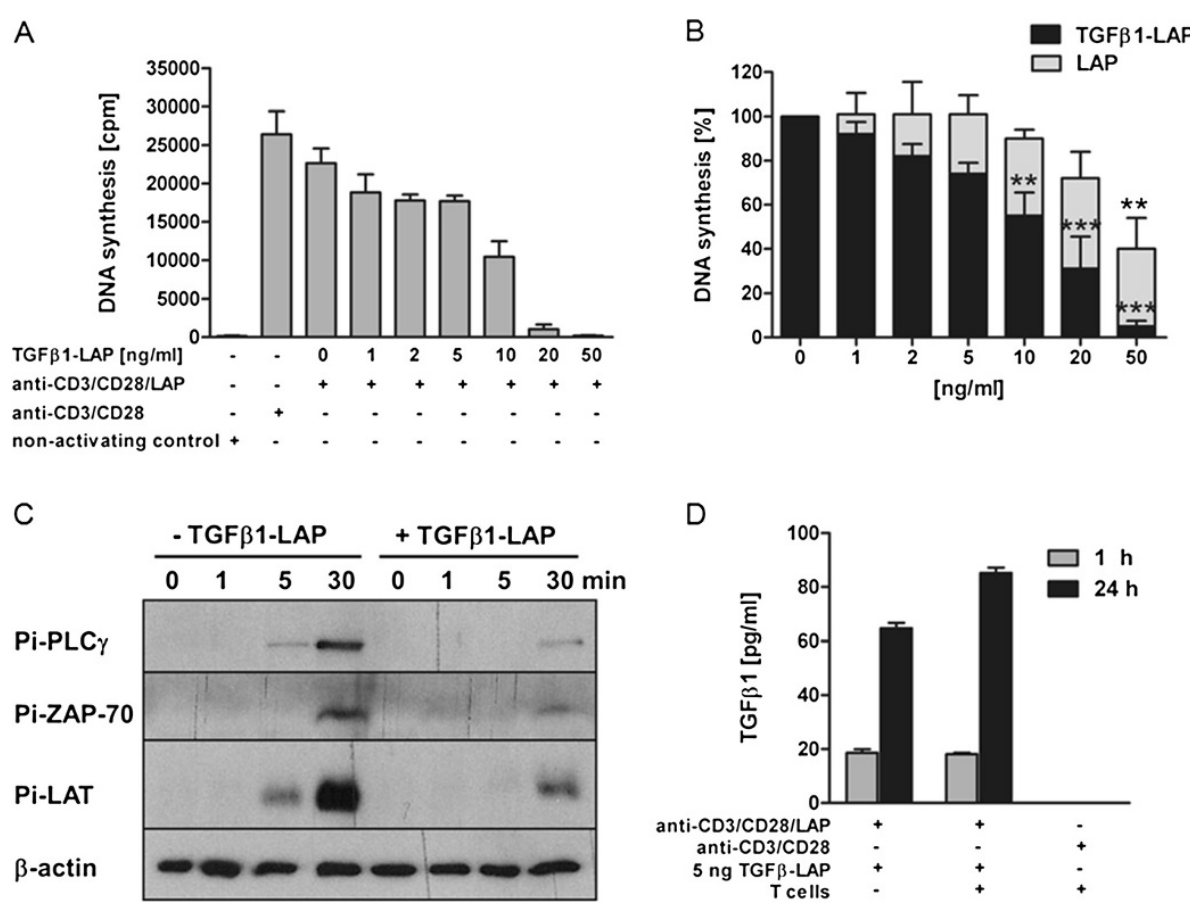

Figure 1 A-D Attenuation of T cell activation response by TGF $\beta 1$-LAP-loaded on anti-CD3/CD28/LAP beads. A) TGFß1-LAP on anti-CD3/ CD28/LAP activating beads, shown in $\mathrm{ng} / \mathrm{ml}$ final concentration, holds back bead-induced proliferation of human T lymphocytes in dose-dependent manner, nearing a complete attenuation at highest doses. Proliferation was assayed by $\left[{ }^{3} \mathrm{H}\right]$ thymidine incorporation, depicted in counts per minute (cpm). Data present averages and SEMs of 3 independent experiments with hexuplicate cultures each. B) Inactive LAP and TGF $\beta 1$-LAP were loaded onto anti-CD3/CD28/LAP beads in parallel titrations. TGF $\beta 1$-LAP on activating beads recapitulated dose-dependent silencing of T cell proliferative response to TCR/CD28 activation. Loading of LAP elicited significant inhibition of proliferation only at highest doses $(n=4)$. ***** depict respective significant difference of $\mathrm{p}<0.01,0.005$ to $100 \%$ proliferation response elicited by anti-CD3/CD28/LAP beads. C) Western blots show that bead-induced tyrosine phosphorylation of TCR-proximal signalling proteins PLCY, ZAP-70, and LAT is attenuated by TGF 31 presentation on anti-CD3/CD28/LAP beads. $\beta$-actin was probed as a loading control. Representative anti-phosphotyrosine blots of 3 independent experiments are shown. D) Gradual release of TGF $\beta 1$ cytokine by TGF $\beta 1$-LAP-loaded beads into the aqueous supernatant of ELISA wells.

and phospholipase $\mathrm{C} \gamma$ (PLC $\gamma$ ), with respective $\mathrm{Mw}$ at $70 \mathrm{kD}, 36 \mathrm{kD}$ and $110 \mathrm{kD}$ (Figure 1C). Importantly, when TGF 31 -LAP was presented by TCR/CD28-activating beads, tyrosine phosphorylation of ZAP-70, LAT, and PLC $\gamma$ was reduced. These data suggest that silencing of $T$ cell activation responses upon TGF $\beta 1$-LAP presentation on TCR/CD28-activating beads commences with attenuation of early TCR-proximal tyrosine phosphorylation.

Holding back $\mathrm{T}$ cell activation response by local presentation of latent TGF 1 -LAP implied mechanisms which release active TGF $\beta 1$-cytokine toward TCR/CD28 activation domains. ELISA analysis of bead supernatants indicated spontaneous release of TGF $\beta 1$-cytokine from beads at a slow rate (Figure 1D) which may be sufficient for the $\mathrm{T}$ cell-silencing mechanism described here. Presence of $\mathrm{T}$ cells elicited an additional $\sim 30 \%$ release of TGF $\beta 1$ at $24 \mathrm{~h} 37^{\circ} \mathrm{C}$ incubation. Association/dissociation kinetics of TGF $\beta$-LAP complexes and of TGF $\beta$ with TGF $\beta R I$ and II were comprehensively characterized in plasmon resonance studies [22], unravelling rates of spontaneous slow dissociation and rapid rebinding of TGF $\beta 1$ to LAP, consistent with our results. In our ELISA assays bead-bound non-complexed LAP molecules compete with TGF $\beta$-capturing ELISA antibodies for binding free TGF $\beta 1$ cytokine. Moreover, T cellular activities partially contribute to latent TGF $\beta 1$-LAP activation. In conclusion, our ELISAs demonstrated gradual release of active TGF $\beta 1$ cytokine from beads but could not estimate quantities and rates in $\mathrm{T}$ cell/bead-conjugates.

TGF $\beta$ and TCR/CD28 signals cooperate in common plasma membrane domains in order to silence $\mathrm{T}$ cell proliferative response

We next queried the requirement of simultaneously presenting TCR/CD28 activating stimulus and TGF $\beta 1$ activity on the same bead for holding back T-cell proliferation (Figure $2 \mathrm{AB}$ ). This was addressed by presenting antiCD3/CD28 stimulus and TGF 1 1-LAP on separate beads (Figure 2A). TGF $\beta 1$-LAP was presented by protein $\mathrm{G}$ beads which were either coated with anti-LAP antibodies alone or with anti-LAP and anti-CD28 antibodies at a 1:1 ratio in order to enhance contact of anti-LAP beads with $\mathrm{T}$ cells. Importantly, both ways of presenting TGF $\beta 1$-LAP to $\mathrm{T}$ cells had little influence on proliferative response 

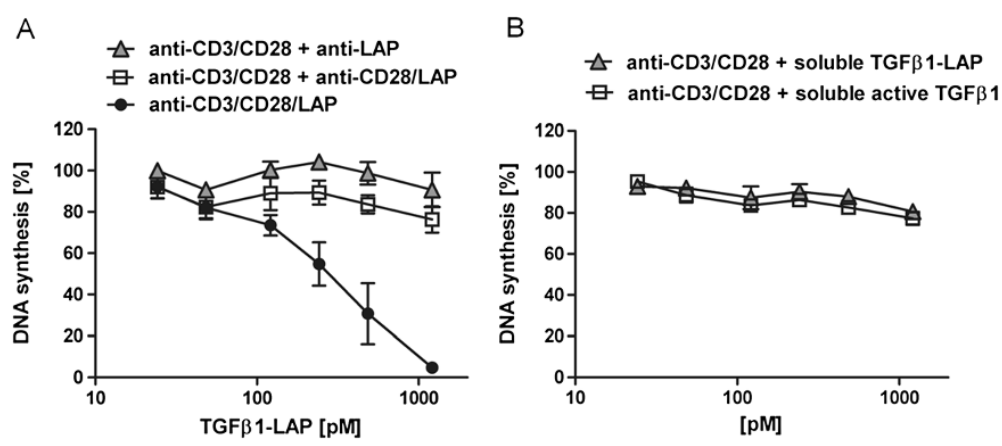

Figure 2 A, B Selective targeting of TGF $\beta 1$ into TCR/CD28 activation sites attenuates $T$ cell proliferation response. A) TGF $\beta 1-L A P$, when presented to human T lymphocytes by anti-LAP- (grey triangles) or anti-LAP/CD28- (white squares) antibody-coated protein G beads, does not inhibit proliferative response elicited by separate anti-CD3/CD28 antibody-coated beads $(n=3)$. TGF $\beta 1$-LAP presented on anti-CD3/CD28/LAP beads (black circles) effectively held back proliferation $(n=4)$. B) Soluble TGF $\beta 1$, as latent TGF $\beta 1$-LAP (black circles) or active TGF $\beta 1$ cytokine (white squares), was present in equimolar amounts as TGF $\beta 1$-LAP for Figures 1A, 2A and did not effectively hold back T cell proliferation induced by activating anti-CD3/CD28 beads.

induced by anti-CD3/CD28 beads. This indicated that stringent silencing of $\mathrm{T}$ cell proliferative response only occurred when TCR/CD28 activating stimuli and TGF 31 LAP were presented to $T$ cells together on the same bead.

TGF $\beta 1$ was presented to T cells as soluble latent TGF $\beta 1$ LAP complex or as soluble active TGF $\beta 1$ cytokine and elicited little antiproliferative effect on $\mathrm{T}$ cells which were activated by anti-CD3/CD28 protein $\mathrm{G}$ beads (Figure $2 \mathrm{~B}$ ). It is particularly important to emphasise that, at this specific setting of T cell activation, soluble active TGF $\beta 1$ cytokine could not substitute for the lack of TGF $\beta 1$ presentation on $\mathrm{T}$ cell activating beads in blocking activation response; suggesting that TCR/CD28- and TGF $\beta$ signals integrate and cooperate in common $\mathrm{T}$ cell plasma membrane domains and then provide signals which silence $\mathrm{T}$ cell activation response. Interestingly, $\mathrm{MHC}$ class II expression identifies a distinct population of human Tregs which mediates early suppression of effector $\mathrm{T}$ cell activation responses on direct cell/cell contact [17]. It is tempting to speculate that silencing beads mimic suppressive activities of this MHC class II + Treg population in the human system.

\section{Diminished proliferative response of bead-silenced T cells to TCR/CD28-activating culture plates}

We observed that TGF $\beta 1$ elicits potent inhibition of T cell proliferative response when presented in physical proximity of activating TCR/CD28 stimuli. We sought to characterize response of these TGF $\beta 1$-silenced $\mathrm{T}$ cells when activated by fresh, independent TCR/CD28 stimulus (Figure $3 \mathrm{AB}$ ). First, $\mathrm{T}$ cells were silenced for $15 \mathrm{~min}$ at $37^{\circ} \mathrm{C}$ with TGF $\beta 1$-LAP on anti-CD3/CD28/LAP beads (Figure $3 \mathrm{~A})$. $\mathrm{T}$ cell/bead conjugates were then transferred to tissue culture plates which were either left untreated or were coated with anti-CD3 and anti-CD28 antibodies.
After 3 days on plates $\mathrm{T}$ cell proliferation rates were determined. ${ }^{3} \mathrm{H}$-thymidin incorporation was used to measure $\mathrm{T}$ cell proliferation rates. On transfer to uncoated non-activating plates proliferation was induced by activating beads without TGF $\beta 1$-LAP loading at $15635 \pm$ $9310 \mathrm{cpm}$ SEM and was taken as $100 \%$ proliferative response value. Variation and relatively low proliferation rates may be caused by variable loss of $\mathrm{T}$ cell/bead contact on transfer. Dose-dependent and stringent antiproliferative action of bead-bound TGF $\beta 1$-LAP, however, was always recapitulated. Transfer of 15 min-incubated T cells/ beads to anti-CD3/CD28-coated tissue culture plates strongly enhanced $\mathrm{T}$ cell proliferation rates. Proliferative response to plate-bound anti-CD3/CD28-activating stimulus was significantly attenuated to $\sim 31 \%$ by TGF $\beta 1$-LAP presentation on initial activating beads. These results indicate that $\mathrm{T}$ cells which were silenced by anti-CD3/CD28/LAP bead-presented TGF $\beta 1$ for 15 min exhibited a reduced response to fresh TCR/CD28 activating surface.

Next, initial bead/T cell activation reactions were incubated for $24 \mathrm{~h}$ before transfer to tissue culture plates (Figure 3B): On transfer to uncoated plates bead-induced proliferation without TGF 31 -LAP was measured at $47881 \pm$ $12792 \mathrm{cpm}$ SEM. Again proliferation of T cells was inhibited by TGF $\beta 1$-LAP loaded on TCR/CD28-activating beads (Figure 3B). Here however, TGF $\beta 1$-mediated suppression of $\mathrm{T}$ cell proliferation was less pronounced than for bead/T cell conjugates after 15 min preincubation in Figure 3A. This suggested that after $24 \mathrm{~h}$ of preincubation silencing activity of TGF $\beta 1$-LAP-loaded TCR/CD28activating beads was reduced, and that silenced $\mathrm{T}$ cells reverted to be receptive to renewed proliferative stimulus by fresh contact with bead-bound anti-CD3/CD28 antibodies on transfer. Indeed, $24 \mathrm{~h}$-preincubated $\mathrm{T}$ cells responded to anti-CD3 and anti-CD28 on plates with little 

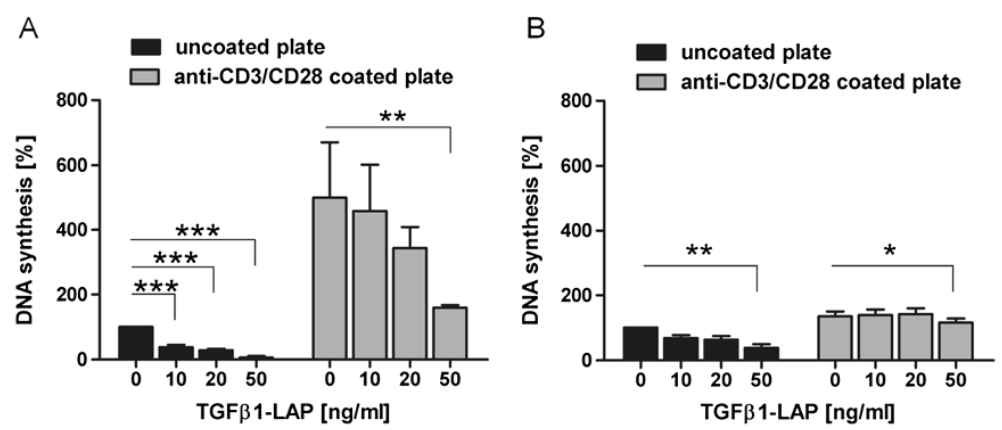

Figure 3 Attenuated proliferative response of bead-silenced T cells to TCR/CD28-activating culture dishes. T cells were incubated in round-bottom tubes with anti-CD3/CD28/LAP beads which were loaded with indicated amounts of TGF 1 1-LAP. After A) $15 \mathrm{~min}$ and B) $24 \mathrm{~h}$ $\mathrm{bead} / T$ cell activation reactions were transferred onto tissue culture plates which were either left untreated (black bars) or were coated with anti-CD3 and anti-CD28 antibodies (grey bars) ${ }^{*}, * *{ }^{* * *}$ depict significant $(p<0.05,0.01,0.005)$ attenuation of proliferation rates when $T$ cells were preincubated with TGF $\beta 1$-LAP on activating beads. A) Transfer of 15 min-incubated bead/T cell conjugates to uncoated plates recapitulated dose-dependent attenuation of T cell proliferation by TGF $\beta 1$-LAP on activating beads. These T cells strongly responded to independent anti-CD3/CD28 stimulus on culture plates. This additional proliferative response was inhibited by initial TGF $\beta 1$-LAP-presentation in dose-dependent manner; down to $\sim 31 \%$ at highest loading of TGF $\beta 1$-LAP $(n=4)$. B) After $24 \mathrm{~h}$ of bead/T cell preincubation T cells responded with additional proliferation to plate-bound anti-CD3/CD28 antibodies. Proliferation on anti-CD3/CD28 plates, however, was restored to nearly the same rates with and without TGF $\beta 1$-LAP preincubation on beads; down to $~ 85 \%$ at highest doses $(n=3)$.

difference in proliferation rates whether the $24 \mathrm{~h}$-preincubation was performed with or without TGF $\beta 1$-LAP on activating beads. In conclusion, silencing of $\mathrm{T}$ cells by TGF $\beta 1$-LAP-loaded beads was reverted on longer incubations and thus did not reflect a long-lasting $\mathrm{T}$ cell anergic state or T cell death (Additional file 1: Figure S1 documents that $\mathrm{T}$ cell viability is unaltered under all experimental conditions).

\section{A range of $T$ cell functions is attenuated when TGF $\beta 1$ is presented on activating beads}

A pan human $\mathrm{T}$ cell cytokine array was used to characterize the range of $\mathrm{T}$ cell effector responses which were silenced by TGF $\beta 1$-presentation on TCR/CD28- activating beads (Figure 4). As expected, activating beads alone induced secretion of cytokines IFN- $\gamma$, IL-2, IL-4, IL-10, IL-17, TNF- $\alpha$. Consistent with attenuated TCRproximal tyrosine phosphorylation and $\mathrm{T}$ cell proliferation, bead-bound TGF $\beta 1$-LAP held back secretion of these cytokines in dose-dependent manner to nearly baseline levels (Figure 4A). T cell effector functions which were attenuated by TGF $\beta 1$-LAP on activating beads included inflammatory responses (TNF- $\alpha$ ), $\mathrm{T}_{\mathrm{H}} 1$ and $\mathrm{T}_{\mathrm{H}} 2$ functions (IFN- $\gamma$, IL-4), $\mathrm{T}_{\mathrm{H}} 17$ functions (IL-17) and regulatory $\mathrm{T}$ cell activities (IL-10). Other cytokines, like IL-8 and IL-16 were secreted by resting $\mathrm{T}$ cells and showed little induction following TCR-activation (Figure 4B). Consistently, secretion of these cytokines was not altered by TGF $\beta 1$ presentation
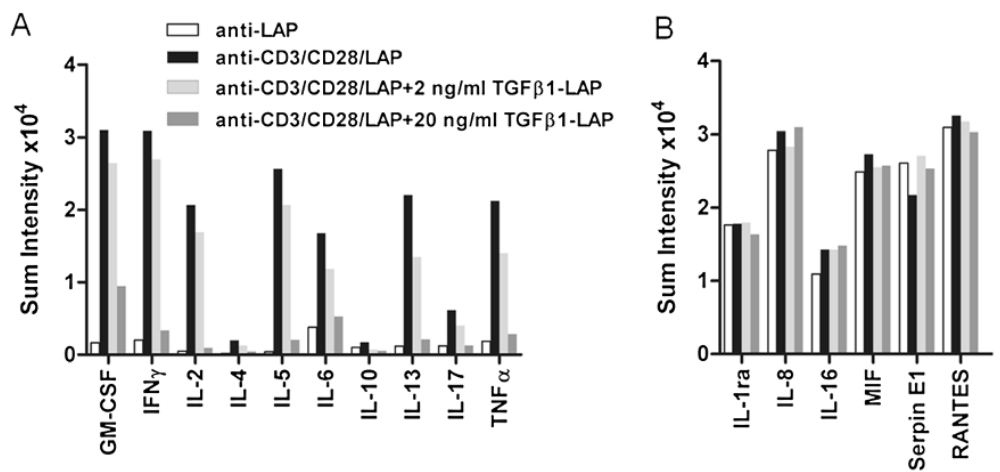

Figure 4 A, B Cytokine array of human pan T cell cytokine secretion-profiles. A) TCR/CD28 activating-antibodies on anti-CD3/CD28/LAP beads induced cytokine secretion (black bars) over non-activating control beads (white bars). Loading of TGF 31 -LAP on these TCR/CD28 activating beads suppressed activation-induced secretion of cytokines in a dose-dependent manner (grey bars). B) Cytokines which were secreted by resting T cells showed little induction following TCR-activation were not affected by TGF 31 on TCR/CD28 activating beads. The cytokine array analysis was performed once and is detailed in Additional file 2: Figure S2. 
on TCR/CD28 activating beads. Cytokine array analysis was performed once and is fully documented in Additional file 2: Figure S2.

\section{TGF $\beta 1$-presentation hinders spreading of T cells over TCR/CD28-activating bead surface}

Next, spreading of $\mathrm{T}$ cells over anti-CD3/CD28/LAP bead surfaces with and without TGF $\beta 1$-LAP loading was characterized by epifluorescence microscopy and statistical analysis (Figure 5). Bead/T cell conjugates, after 45 min incubation at $37^{\circ} \mathrm{C}$, were stained with Alexa488 fluorescent anti-actin $\mathrm{mAb}$ to visualize the circumference of $\mathrm{T}$ cells, and protein $\mathrm{G}$ beads were additionally marked with Alexa555 mouse IgG1. Consistent with previous reports, anti-CD3/CD28/LAP antibodies alone induced $\mathrm{T}$ cell-spreading over the surface of TCR/CD28-activating beads leading to their engulfment (Figure 5A) and actincontaining structures formed at the edges of the beads while actin was depleted from the central region of beadcell contact $[23,24]$. Importantly, loading of TGF $\beta 1$-LAP on activating beads significantly inhibited engulfment of TCR/CD28-activating beads (Figure 5B, C). Inhibition of T cell spreading over TCR-activating surfaces was reported to attenuate $\mathrm{T}$ cell activation response [23,25].

\section{Conclusions}

Pleiotropic action and consequent severe side effects preclude use of active TGF $\beta$ in medical applications for the treatment of pathological conditions connected to unwanted T cell activity [26]. Our findings suggest a new strategy to circumvent these difficulties by selective targeting of TGF $\beta 1$ to TCR activation plasma membrane domains in order to specifically silence $\mathrm{T}$ cell responses. Bifunctional biologicals which link functions of TCR activation and TGF $\beta R I$ and II activation proximally in the plasma membrane promise applications in therapy of disease associated to unbalanced, unwanted $\mathrm{T}$ cell activity in autoimmunity, allergy or transplant rejection.

\section{Methods}

\section{Materials}

Protein G-coated dynabeads were obtained from Novex Life technologies. Pan T cell isolation kit II was from Miltenyi Biotec. HIT3a anti-CD3 mAb and CD28.2 anti-CD28 mAb were from Becton Dickinson. AntiLAP-TGF $\beta$ mAb; latent TGF $\beta 1$; active TGF $\beta 1$ cytokine, cytokine array kit and TGF $\beta$ cytokine ELISA assay were from R\&D Systems. Anti-phospho-PLC 1 (Tyr783), anti-phospho-Zap-70 (Tyr319), and anti-phospho-LAT (Tyr191) were obtained from Cell Signaling Technology, anti- $\beta$-Actin monoclonal antibody from Sigma. HRPconjugated donkey anti-mouse IgG or donkey anti -rabbit IgG (Dianova, Hamburg, Germany) were used as secondary antibodies. Ficoll was from Biochrome, $\left[{ }^{3} \mathrm{H}\right]$ thymidine from MP Biomedicals, AIM-V culture medium from Invitrogen.
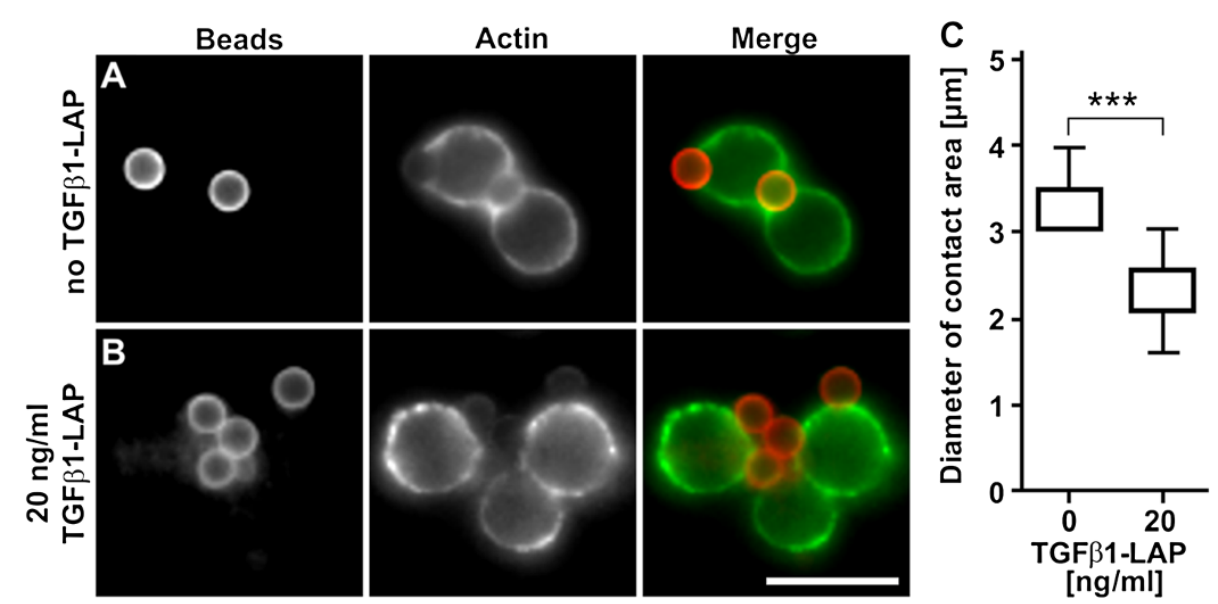

Figure 5 A, B Spreading of T cells over TCR/CD28-activating bead surface. Isolated human resting T cells were conjugated with anti-CD3/ CD28/LAP beads and incubated at $37^{\circ} \mathrm{C}$ for $45 \mathrm{~min}$ and analysed by fluorescence microscopy. Outline of T cells was marked with fluorescent Alexa488 anti-actin mAb (in green in merged image, please note weak binding of Alexa488 mAb to protein $\mathrm{G}$ beads), protein $\mathrm{G}$ beads with Alexa555 lgG1 mAb (in red). A) Anti-CD3/CD28/LAP beads triggered spread of cells over bead surface leading to their partial or complete engulfment. Actin was depleted from the centre of bead/ T cell contact region and actin-rich lamellipodia formed at the periphery. B) TCR/ CD28-mediated bead-engulfment by T cells and actin reorganisation was suppressed in conjugates with TGF $\beta 1$-presenting activating beads. Scale bar $=10 \mu \mathrm{m}$. C) Bar graphs indicate diameter of contact area of $23(0 \mathrm{ng} / \mathrm{ml}$ TGF $\beta 1)$ or $14(20 \mathrm{ng} / \mathrm{ml} \mathrm{TGF} \beta 1)$ bead/cell conjugates in two independent experiments. Boxes mark the $25 \%$ and $75 \%$ percentiles and error bars $5 \%$ and $95 \%$ percentiles of the contact secants. ${ }^{* * *}$ mark significant difference of $\mathrm{p}<0.0001$ in two-tailed Mann-Whitney testing. Please note that $5 \%$ and $25 \%$ percentiles in data sets of $0 \mathrm{ng} / \mathrm{ml}$ TGF $\beta 1$ cannot be graphed separately. 


\section{Isolation of resting human T cells}

Human peripheral blood mononuclear cells (PBMC) were isolated by Ficoll gradient centrifugation of heparinized blood collected from healthy volunteers. Human $\mathrm{T}$ cells were further purified by non- $\mathrm{T}$ cell depletion using the Pan T cell isolation kit II (Miltenyi Biotec). Purity of isolated pan $\mathrm{T}$ cells was $\geq 99 \%$. Cells were washed twice and resuspended in serum-free AIM-V culture medium (Invitrogen). The study was approved by the local ethics committee of the Medical Faculty of the Otto-vonGuericke University Magdeburg. Blood donors gave written informed consent.

\section{Ligand-coating of beads, ELISA analysis, and preparation of anti-CD3/CD28 antibody-bound tissue culture plates}

$0.6 \mathrm{mg}$ of protein $\mathrm{G}$ dynabeads were coated with $11 \mu \mathrm{g}$ of antibody mix; anti-CD3, anti-CD28 and anti-LAP antibodies at 1:5:5 ratios; anti-LAP, anti-CD28 antibodies at 1:1 ratios, or anti-LAP antibodies alone. After wash in $2 \times 1 \mathrm{ml}$ PBS, $0.5 \%$ BSA beads were suspended in $800 \mu \mathrm{l}$ PBS, 0.5\% BSA for microscopy, ELISAs, array analysis, and proliferation assays or in $80 \mu \mathrm{l}$ PBS, $0.5 \%$ BSA for preparing Western blot samples. Antibody-coated beads in required minimal volumes were incubated with TGF $\beta 1$ LAP to achieve final concentrations of $0,0.1,0.2,0.5,1,2$, and $5 \mathrm{ng} / 4 \mu \mathrm{l}$ of bead suspension. Anti-CD3/CD28/LAP beads for Western blot samples were loaded to $20 \mathrm{ng}$ TGF $\beta 1-L A P / 4 \mu \mathrm{l}$ suspension. Bead/TGF $\beta 1$-LAP mix was incubated $\mathrm{o} / \mathrm{n}$ on a rotating wheel at $4^{\circ} \mathrm{C}$, suspended in $1 \mathrm{ml}$ of PBS, $0.5 \%$ BSA in ice and harvested with a magnet. Pelleted beads were then suspended in PBS, 0.5\% BSA, retaining above concentrations of beads and bead-bound TGFß1-LAP.

ELISA: $3 \mu \mathrm{g}$ anti-CD3/CD28/LAP protein G beads were loaded with $5 \mathrm{ng}$ latent TGF 31 -LAP, transferred into $100 \mu \mathrm{l}$ AIMV medium in commercial TGF $\beta$-ELISA wells (BD Life Technologies) and incubated for $1 \mathrm{~h}$ (grey bars) and $24 \mathrm{~h}$ (black bars) at $37^{\circ} \mathrm{C} \cdot 10^{5} \mathrm{~T}$ cells were present in some wells. Plates were developed according to manufacturer's instruction in quadruplicate wells per condition.

Plastic tissue culture plates were coated with goat antimouse secondary antibodies (Dianova) 1:100 in PBS $50 \mu \mathrm{l} /$ well $\mathrm{o} / \mathrm{n}$ at $4^{\circ} \mathrm{C}$, washed in PBS, and then incubated for $1 \mathrm{~h}$ with hybridoma supernatants of anti-CD3 (Okt3) and anti-CD28 (CD28.2) monoclonal antibodies; 1:100 in PBS.

\section{Proliferation-, cytokine secretion-assay, viability assessment and Western blot}

$10^{5} \mathrm{~T}$ cells were incubated with $4 \mu \mathrm{l}\left(2 \times 10^{5}\right)$ of respective ligand-coated beads in round bottom wells of 96 well microtiter plates (Nunc) with $100 \mu \mathrm{l}$ of serum-free AIM-V medium (six wells per condition). Proliferation was assessed after 3 days by measuring $\left[{ }^{3} \mathrm{H}\right]$ thymidine $\left[{ }^{3} \mathrm{H}-\mathrm{TdR}\right]$ incorporation. $\left[{ }^{3} \mathrm{H}\right]$ thymidine was added at $0.2 \mu \mathrm{Ci} /$ well for $3 \mathrm{~h}$.
At the end of the incubation period, cells were harvested and radioisotope incorporation was measured as index of lymphocyte proliferation using a betaplate liquid scintillation counter (MicroBeta, Wallac).

Cytokine secretion profile following 3 days of cell/bead incubation was determined from 10x100 $\mu \mathrm{l}$ AIM-V T cell supernatant per condition and was assayed using commercial cytokine array kit (R\&D) according to manufacturer's instruction. Semi-quantitative analysis was performed by determining the background-subtracted sum intensity for each dot on the membrane using Kodak D1 3.6 software. Densitometry values of spots on different membranes were normalized using the results for the positive controls.

Data were analysed, graphed, and subjected to statistical analyses using Graphpad Prism software.", ***, **** depict statistical significance $\mathrm{p}<0.05,0.01,0.005$, respectively assessed by one way Anova testing.

Cell viability was determined in parallel cell cultures by propidium iodide (PI) staining. After $4 \mathrm{~h}, 24 \mathrm{~h}$, and $72 \mathrm{~h}$ of incubation with respective activating beads, cells were incubated with PI/RNase staining buffer (BD Pharmingen) for $15 \mathrm{~min}$ and percentage of PI-excluding cells was subsequently determined by FACS according to manufacturer's instructions.

For Western blot analyses whole cell lysates were prepared from $10^{6} \mathrm{~T}$ cells in $20 \mu \mathrm{l}$ AIM-V medium. T cells were incubated with $4 \mu \mathrm{l}\left(2 \times 10^{6}\right)$ TCR/CD28 activating beads with and without TGF $\beta 1$-LAP coating, incubated at $37^{\circ} \mathrm{C}$ for $0,1,5,30 \mathrm{~min}$, and lysed in a final volume of $100 \mu \mathrm{l} 1 \mathrm{x}$ SDS sample buffer. Proteins, $20 \mu \mathrm{l}$ sample per lane, were separated in 10\% SDS-polyacrylamide gel and transferred to Hybond $\mathrm{N}$ membranes by semi-dry blotting. Specific binding was visualized by chemiluminescence (Thermo Scientific, Rockford, USA).

\section{Microscopy}

$\mathrm{Bead} / \mathrm{Cell}$ conjugates were incubated at $37^{\circ} \mathrm{C}$ for $45 \mathrm{~min}$ and adhered to poly-L-lysine coated microscopy slides. After 15 min fixation with 2\% PFA cells were permeabilised for 10 min with $0.2 \%$ TX100 in PBS, washed in PBS/ 1\% BSA for $30 \mathrm{~min}$. Actin of cells was labelled with an Alexa488 conjugated anti- actin antibody (BD, 558623) and protein $\mathrm{G}$ beads were marked with Alexa555-labelled IgG1 mAb (Cell Signaling). Fluorescence images were recorded with a CCD camera (Apogee, KX4) mounted to a fluorescence microscope (Leica, DM IRE2) using Alexa488 (Omega Filters, XF116-2) and Alexa555 (Omega Filters, XF111-2) channel settings at $63 \mathrm{x}$ magnification (Leica, Oil, NA 1.40, 506206). Maximal lengths of the secants in 14 (20 ng TGF $\beta 1-L A P)$ and 23 (0 ng TGF $\beta 1-$ $\mathrm{LAP})$ at the respective bead/cell contact zones was measured. $*$ mark significant inhibition $(\mathrm{p}<0.0001)$ of bead engulfment by TGF $\beta 1$-LAP-loading in two tailed MannWhitney testing. 


\section{Additional files}

Additional file 1: Figure S1. Viability of T cells is unchanged on presentation of TGF $\beta 1$-LAP on TCR/CD28-activating beads. Bead T cell conjugates were incubated for indicated times at $37^{\circ} \mathrm{C}$ and percentage of viable, propidium iodide-excluding cells was determined by FACS analysis.

Additional file 2: Figure S2. Documentation; Cytokine array analysis. A) Arrangement of cytokine-trapping antibodies on array, B) Chemiluminescence film exposure C) Semi-quantitative analysis of cytokine-chemiluminescence signals using software Kodak D1 3.6.

\section{Competing interests}

Use of bifunctional biologicals which activate TGF $\beta$ and TCR signalling in physical proximity in the plasma membrane in order to silence T cell activation responses is filed as European Patent application 13005586.6 - 1412.

\section{Authors' contributions}

$\mathrm{TH}$ and DR designed and led the experiments, and TH wrote the paper. KG and LS performed T cell activation assays, and LP microscopic characterisations. BS and TH originally posed the immunological question and DR enabled realisation of the approach. All authors read and approved the final manuscript

\section{Acknowledgments}

This work was performed at the Institute for Molecular and Clinical Immunology, Otto-von-Guericke University Magdeburg, Leipziger Straße 44, D 39120 Magdeburg, Germany.

This research was supported by the "Initial Funding" program of the Center of Dynamic Systems (CDS); Biosystems Technology, Magdeburg and by the SFB854 of the Deutsche Forschungsgemeinschaft.

Received: 9 July 2014 Accepted: 3 November 2014

Published online: 08 December 2014

\section{References}

1. Massague J: TGFbeta signalling in context. Nat Rev Mol Cell Biol 2012, 13:616-630.

2. Li MO, Flavell RA: TGF-beta: a master of all T cell trades. Cell 2008, 134:392-404.

3. Tran DQ: TGF-beta: the sword, the wand, and the shield of FOXP3(+) regulatory T cells. J Mol Cell Biol 2012, 4:29-37.

4. Marie JC, Liggitt D, Rudensky AY: Cellular mechanisms of fatal early-onse autoimmunity in mice with the T cell-specific targeting of transforming growth factor-beta receptor. Immunity 2006, 25:441-454

5. Li MO, Sanjabi S, Flavell RA: Transforming growth factor-beta controls development, homeostasis, and tolerance of $\mathrm{T}$ cells by regulatory $\mathrm{T}$ cell-dependent and -independent mechanisms. Immunity 2006, 25:455-471.

6. Shull MM, Ormsby I, Kier AB, Pawlowski S, Diebold RJ, Yin M, Allen R, Sidman C, Proetzel G, Calvin D, Annunziata N, Doetschman T: Targeted disruption of the mouse transforming growth factor-beta 1 gene results in multifocal inflammatory disease. Nature 1992, 359:693-699.

7. Kulkarni AB, Huh CG, Becker D, Geiser A, Lyght M, Flanders KC, Roberts AB, Sporn MB, Ward JM, Karlsson S: Transforming growth factor beta 1 null mutation in mice causes excessive inflammatory response and early death. Proc Natl Acad Sci U S A 1993, 90:770-774.

8. Worthington JJ, Fenton TM, Czajkowska Bl, Klementowicz JE, Travis MA: Regulation of TGFbeta in the immune system: an emerging role for integrins and dendritic cells. Immunobiology 2012, 217:1259-1265.

9. Annes JP, Munger JS, Rifkin DB: Making sense of latent TGFbeta activation. J Cell Sci 2003, 116:217-224.

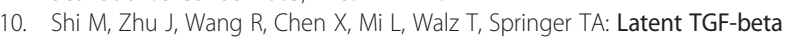
structure and activation. Nature 2011, 474:343-349.

11. Kane $L P$, Lin J, Weiss A: Signal transduction by the TCR for antigen. Curr Opin Immunol 2000, 12:242-249.

12. Riha $P$, Rudd CE: CD28 co-signaling in the adaptive immune response. Self Nonself 2010, 1:231-240.

13. Nakamura K, Kitani A, Strober W: Cell contact-dependent immunosuppression by CD4(+)CD25(+) regulatory $T$ cells is mediated by cell surface-bound transforming growth factor beta. J Exp Med 2001, 194:629-644.
14. Oida T, Weiner HL: TGF-beta induces surface LAP expression on murine CD4 T cells independent of Foxp3 induction. PLoS One 2010, 5:e15523.

15. Stockis J, Colau D, Coulie PG, Lucas S: Membrane protein GARP is a receptor for latent TGF-beta on the surface of activated human Treg. Eur J Immunol 2009, 39:3315-3322.

16. Tran DQ, Andersson J, Wang R, Ramsey H, Unutmaz D, Shevach EM: GARP (LRRC32) is essential for the surface expression of latent TGF-beta on platelets and activated FOXP3+ regulatory T cells. Proc Natl Acad Sci U S A 2009, 106:13445-13450.

17. Baecher-Allan C, Wolf E, Hafler DA: MHC class II expression identifies functionally distinct human regulatory T cells. J Immunol 2006, 176:4622-4631.

18. Travis MA, Reizis B, Melton AC, Masteller E, Tang Q, Proctor JM, Wang Y, Bernstein X, Huang X, Reichardt LF, Bluestone JA, Sheppard D: Loss of integrin alpha(v)beta8 on dendritic cells causes autoimmunity and colitis in mice. Nature 2007, 449:361-365.

19. Melton AC, Bailey-Bucktrout SL, Travis MA, Fife BT, Bluestone JA, Sheppard D: Expression of alphavbeta8 integrin on dendritic cells regulates Th17 cell development and experimental autoimmune encephalomyelitis in mice. J Clin Invest 2010, 120:4436-4444.

20. Acharya M, Mukhopadhyay S, Paidassi H, Jamil T, Chow C, Kissler S, Stuart LM, Hynes RO, Lacy-Hulbert A: Alphav Integrin expression by DCs is required for Th17 cell differentiation and development of experimental autoimmune encephalomyelitis in mice. J Clin Invest 2010, 120:4445-4452.

21. Harder T, Kuhn M: Selective accumulation of raft-associated membrane protein LAT in T cell receptor signaling assemblies. J Cell Biol 2000, 151:199-208.

22. De Crescenzo G, Grothe S, Zwaagstra J, Tsang M, O'Connor-McCourt MD: Real-time monitoring of the interactions of transforming growth factor-beta (TGF-beta) isoforms with latency-associated protein and the ectodomains of the TGF-beta type II and III receptors reveals different kinetic models and stoichiometries of binding. J Biol Chemistry 2001, 276:29632-29643.

23. Bunnell SC, Kapoor V, Trible RP, Zhang W, Samelson LE: Dynamic actin polymerization drives $T$ cell receptor-induced spreading: a role for the signal transduction adaptor LAT. Immunity 2001, 14:315-329.

24. Lowin-Kropf B, Shapiro VS, Weiss A: Cytoskeletal polarization of T cells is regulated by an immunoreceptor tyrosine-based activation motif-dependent mechanism. J Cell Biol 1998, 140:861-871.

25. Campi G, Varma R, Dustin ML: Actin and agonist MHC-peptide complex-dependent T cell receptor microclusters as scaffolds for signaling. J Exp Med 2005, 202:1031-1036.

26. Calabresi PA, Fields NS, Maloni HW, Hanham A, Carlino J, Moore J, Levin MC, Dhib-Jalbut S, Tranquill LR, Austin H, McFarland HF, Racke MK: Phase 1 trial of transforming growth factor beta 2 in chronic progressive MS. Neurology 1998, 51:289-292.

doi:10.1186/s12964-014-0074-6

Cite this article as: Harder et al:: Selective targeting of transforming growth factor-beta1 into TCR/CD28 signalling plasma membrane domains silences $T$ cell activation. Cell Communication and Signaling 2014 12:74

\section{Submit your next manuscript to BioMed Central and take full advantage of:}

- Convenient online submission

- Thorough peer review

- No space constraints or color figure charges

- Immediate publication on acceptance

- Inclusion in PubMed, CAS, Scopus and Google Scholar

- Research which is freely available for redistribution 